discovery that neon, which is comparatively poor in ultra-violet light, can by using suitable powders be made to excite luminescence. These luminescent materials will probably be largely used in electric discharge lamp lighting. They will add the missing colours to light given out by vapours and gases, thus making objects illuminated by them appear as they do in daylight.

It was found four years ago that very great yields of light could be obtained from the passage of electricity through mercury vapour, if the pressure of the vapour was increased to about one atmosphere instead of using only one hundredth of an atmosphere as in the older types of lamp. This has led to the improved lighting of hundreds of miles of streets in Britain. There are now about 15,000 street lighting posts fitted with these lamps.

Light is becoming so cheap that it is foolish not to make full use of it. Its liberal use contributes greatly to safety. It enhances the beauty of our homes and increases the efficiency of our workshops. Gardens and highways at night can be made beautiful by its use. Blackpool, perhaps more than any other town, has improved its amenities by using artificial light. Incidentally, this gives a royal welcome to its visitors.

\title{
Plant Hunting and Exploration in Tibet
}

\section{$\mathrm{T}$} HE second evening discourse at the Blackpool meeting of the British Association was delivered on September 15 by Capt. F. Kingdon-Ward. He said that however much we may regret some of the results of the industrialization of Britain-the destruction of forest, the urbanization of pasture land, slums, and so on-our country is in some respects a vast improvement on the England of four centuries ago. It was then a colourless land, especially during the winter. Thanks to the great interest taken in horticulture and sylviculture to-day, it is that no longer. About twelve thousand species of introduced trees, shrubs and herbs are cultivated in the opennearly ten times the total number of flowering plants which occur wild. Thus the British climate must be singularly elastic, and the plants themselves highly adaptable. Probably in no other country in the world of equal area can so many alien plants be grown. Some are difficult, but more are easy, and not a few naturalize themselves.

Tibet, the highest plateau in the world, is not as is generally supposed a complete desert. There is a gradual increase in the flora from west to east, and from north to south, corresponding with the change in the physiographical nature of the country; the vegetation slowly changes from tundra to scrub and grassland, and from scrub to forest. Naturally, the most prolific and varied flora is found in the forested south-eastern region. This flora is a mixed one. The climate varies greatly from warm temperate at the bottom of the gorges where Tibet reaches its lowest altitude at 5,000 feet, to subarctic on the high snow- clad ranges the peaks of which attain 25,000 feet. All adjacent regions-China, Indo-Malaya, the Himalaya-have contributed to the flora of Tibet. Not every plant found there is hardy in Britain, but a surprising number are. Nor is it possible to forecast whether a given plant will be hardy or not; experience enables one to make a shrewd guess, but no more. On the whole, the plants which have proved most adaptable to our gardens are those which are not found growing under extreme conditions; that is to say, the plants, not of the tundra, nor of the deep forested river gorges, nor of the highest alpine ranges, but those of the intermediate scrubclad plateau country, at 10,000-12,000 feet altitude.

Throughout the summer, one is busy collecting plants in flower. In late autumn, one starts harvesting seeds. It is not necessary to mark the plants when in flower, of which seed is required. Most plants are found over extensive areas where the climatic conditions are similar, and constant practise enables one to recognize a given plant by its fruits as readily as by its flowers. Particular plants occur in prodigious numbers; most species are at least common; the difficulty is to discover a rare plant! Capt. KingdonWard said that he could recall very fow of which he discovered but one specimen-Leycesteria crocothyrros is one of them.

Tibet has become famous as the land of the blue poppy (Meconopsis betonicifolia) and the scarlet creeping rhododendron ( $R$. repens). But it is equally the home of many other beautiful flowers, as gentians, lilies, barberries, primulas and many more.

\section{Science at the International Peace Congress}

CCIENTIFIC concern for the preservation of $\checkmark$ world peace found abundant expression at the International Peace Congress held at Brussels on September 3-6. Special commissions considered the bearing of art, science and letters, medicine, agriculture and education on the problems of peace and war, the report of the Science Sub-Commission, formed by a small but internationally representative body of scientific workers under the chairmanship of Dr. J. D. Bernal of Cambridge, being typical of the constructive attitude of the professional delegates.

This committee clearly recognized the effects of war in disintegrating the humane purpose and international character of science, and declared that scientific workers should do their utmost to strengthen international amity not only by a general determination to oppose war but also by definite practical activity. "We have to consider," it decided, "how we can best assist in preventing an immediate 